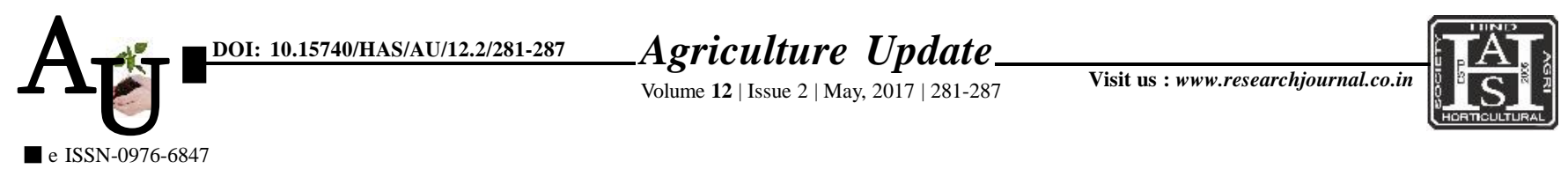

\title{
Rеsевсн автіст: The incidence of labour-land and labour-credit interlocking in agriculturally developed region of Rajasthan
}

\section{R.C. ASIWAL, R.C. SHARMA AND BASANT KUMAR SHARMA}

Article Chronicle: Received :

01.03.2017;

Revised :

05.04.2017;

Accepted :

20.04.2017

KeY WoRds:

Interlocking,

Probability,

Household,

Incidence, Implicit,

Explicit, Functioning

Author for correspondence :

\section{R.C. ASIWAL}

Department of

Agricultural Economics,

S.K.N. College of

Agriculture, JOBNER

(RAJASTHAN) INDIA

Email:rameshasiwal23@

gmail.com

See end of the article for

authors' affiliations
SUMMARY : The present study investigates the functioning of Agricultural labour market in Jaipur district of Rajasthan. The Chomu tehsil was purposively selected for study. A cluster of three villages namely, Jaitpura, Kanpura and Khushalpura was randomly selected from the selected tehsil. From above selected villages, a sample of sixty respondents was selected at random with the help of probability proportion. Primary data were collected from the selected agricultural labour households by personally interviewing the results of study revealed that more than 80 per cent of the households reported either borrowing or leasing in land from their employers in all selected villages. Further, labour-credit interlocking was much more pronounced as compared to labour-land interlocking. The number of days worked on lower wages per annum varied from as high as 81.00 in Khushalpura to 61.00 in Jaitpura. The implicit rate of interest varied between as high as 36.00 per cent in Khushalpura and 24.00 per cent in Jaitpura. The incidence of hereditary debt was reported only in one sample villages, which was Rs. 12500 in Khushalpura. The incidence of labour land interlocking was very low; it varied from 14 per cent to around 18 per cent sample households involved in such interlocking. The low incidence of labour land interlocking was primarily due to the fact that most of the agricultural labour households did not have the supporting inputs, like bullocks and other farm implements which are essentially required in farming.

How to cite this article : Asiwal, R.C., Sharma, R.C. and Sharma, Basant Kumar (2017). The incidence of labour-land and labour-credit interlocking in agriculturally developed region of Rajasthan. Agric. Update, 12(2): 281-287; DOI : 10.15740/HAS/AU/12.2/281-287. 